\title{
Using contribution analysis to assess the influence of farm link programs in the U.S.
}

Angela Hersey ${ }^{a} *$ and Michelle Adams ${ }^{b}$

Dalhousie University

Submitted September 5, 2016 / Revised February 20 and April 18, 2017 / Accepted April 18, 2017 /

Published online July 11, 2017

Citation: Hersey, A., \& Adams, M. (2017). Using contribution analysis to assess the influence of farm link programs in the U.S. Journal of Agriculture, Food Systems, and Community Development, 7(3), 83 -103.

http://dx.doi.org/10.5304/jafscd.2017.073.006

Copyright (C) 2017 by New Leaf Associates, Inc.

\begin{abstract}
This paper examines 12 U.S. farm link programs (FLPs) using a type of program evaluation called contribution analysis (CA) to determine if FLPs are effective in facilitating farmland transfers between retirement-aged farmers without family successors and new farmers beginning their career. CA guided the data collection, which included web audits, interviews, questionnaires, and scholarly and grey literature review. We developed an analytical framework in the form of a theory of change, followed by analysis of the FLPs and their contribution to farm transfers. The analysis focused on four themes that emerged from the theory of change: (1) the effectiveness of FLP
\end{abstract}

a * Corresponding author: Angela Hersey, School for Resource and Environmental Studies, Dalhousie University; 6100 University Avenue; P.O. Box 15000; Halifax, Nova Scotia B3H 4R2 Canada; +1-902-802-0117; angela.hersey@dal.ca

Permanent address: 1-83 Queen Street; Dartmouth, Nova Scotia B2Y 1 G7 Canada.

b School for Resource and Environmental Studies, Dalhousie University; 6100 University Avenue; P.O. Box 15000; Halifax, Nova Scotia B3H 4R2 Canada; michelle.adams@dal.ca design and program activities; (2) the usefulness of FLP databases to meet the needs of farmers; (3) farmer motivation toward development or land preservation; and (4) trends and systemic influences on farm transfers. Although some FLPs experienced relative success, the lack of professional support systems, a heavy reliance on a self-serve Internet database, and the presence of various external conditions prevent most FLPs from facilitating substantial numbers of farm transfers. To conceptualize how FLPs may be more successful, a revised theory of change was developed, offering new perspectives on the systemic conditions in which FLPs operate.

\section{Keywords}

Contribution Analysis; Family Farm; Farm Link Programs; Farm Transfers; Retiring Farmers; Succession Planning

\section{Introduction}

In the U.S., farm link programs (FLPs) endeavor to preserve productive agricultural land by facilitating farm transfers from retiring farmers or landowners 
to those starting a farming career (Hubbard, 2006). FLPs also look to other types of arrangements to support this transition, such as short- or long-term leases. Nonprofit organizations, universities, and outreach arms of government departments typically run FLPs, also known as 'land link' programs (Hubbard, 2006). Their overall intent is to keep farmland "in agricultural production while helping preserve rural communities and family farms in the face of ever-growing corporate interests" (Slack, 2013, p. 505). FLPs hope to enable farmers to retire comfortably, make affordable land accessible to beginning farmers, and limit the loss of farmland to development.

The literature describes mostly what FLPs do and how they function (Goeller, 2012; Hubbard, 2006; Slack, 2013; Strange, Thompson, Prosch, \& Johnson, 2003). Ingram and Kirwan (2011), however, explore the difficulties FLPs face through the lens of the challenges and ultimate dissolution of the Fresh Start FLP in Cornwall, U.K. They suggest that it is nearly impossible for FLPs to account for, and thereby mitigate, the 'social factors' that influence farm transfers, such as lack of trust between retiring and new farmers (Ingram \& Kirwan, 2011). Their critique highlights the fact that research on the ultimate effectiveness of FLP efforts is lacking.

The intent of our research was to evaluate the capacity of FLPs to facilitate various types of farm transfers while identifying barriers and challenges that may interfere with this goal. The research was undertaken using the program evaluation framework contribution analysis (CA). With CA as a guide, we analyzed literature and interview data from FLP staff in order to position FLPs in the broader scheme of farm transfers in the U.S. We also analyzed the environments in which FLPs operate to identify some general program design flaws as well as the ability of the programs to facilitate farm transfers effectively.

\section{Literature Review}

Farmland occupies roughly 40 percent (914 million acres) of privately owned U.S. land (Daniels \& Bowers, 1997; Nickerson, Morehart, Kuethe, Beckman, Ifft, \& Williams, 2012). Total acreage, however, has decreased since the shift to industrial agricultural production began in 1935 (U.S. Environmental Protection Agency [U.S. EPA], 2013). Large farms dominate agricultural production, and smaller family-run farms have been going out of business (Hamilton, 2005; Lyson, 2007). Each year up to 500,000 acres $(202,343$ hectares) of farmland is lost and developed. Between 1982 and 2010, about 24,125,400 acres $(9,763,203$ hectares) were lost (Farmland Information Center, 2013). As urban areas expand, the economic value of farmland increases (Kuethe, Ifft, \& Morehart, 2011). In the 2000s, farmland values increased significantly (Gloy, Boehlje, Dobbins, Hurt, \& Baker, 2011; Weber \& Key, 2015), influencing the ability of new farmers to afford farmland. Moreover, three-quarters of new farmers do not come from a farming family who could help them access land and capital (Ahearn \& Newton, 2009; Inwood, 2013; Inwood, Clark, \& Bean, 2013; Mailfert, 2007).

Urban sprawl-the expansion of urban and suburban areas onto rural land-can cause farmers to perceive development as inevitable, thus affecting their desire to update their agricultural model (Lindstrom \& Bartling, 2003). "Farmers often feel discouraged from taking creative action to continue farming and are put in a financial situation where they need to sell quickly" (Lindstrom \& Bartling, 2003 , p. 2), so farmers often sell their farm for less than market value, a cycle that leaves farmers without adequate retirement income while encouraging continued suburbanization.

Many aging farmers have no familial successors (Scott, Cameron, \& Benjamin, 2010). Traditionally, farms are passed on to children as farmers approach retirement age, but the difficulties of farming encourage farmers' children to pursue other careers (Ball \& Wiley, 2005). The average age of farmers in the U.S. is 58, up from 55 in 2002, and the number of farmers over 75 has increased 20 percent since 2002 (U.S. Department of Agriculture [USDA], 2007a, 2012). Without successors, farmers work well beyond traditional retirement age (Amshoff \& Reed, 2005; Ball \& Wiley, 2005), and without adequate succession plans, the future of their farms may be at risk.

By 2019, about 10 percent ( 91.5 million acres or 37 million hectares) of farmland will change 
hands (USDA, 2014). Many farmers will need to sell their farms, but to whom and for how much? Those wanting to enter farming often struggle with high start-up costs and obtaining land, despite their willingness to enter the profession (Ingram \& Kirwan, 2011) and often cannot purchase land at a price that enables financial security for retiring farmers (Pitts, Fowler, Kaplan, Nussbaum, \& Becker, 2009), thereby making farm transfers impracticable. When developers offer good prices for farmland, it is understandable that a farmer without a successor would sell land to finance retirement. Research that can help unpack the nuances of supporting more successful farm transfers is important to disrupt this trend.

\section{Methods and Analytical Approach}

We based the methodological framework for this research on a Program Evaluation (PE) method called contribution analysis (CA), first developed by John Mayne in 2001 (Mayne, 2012). CA accounts for the fact that external factors may have more of an impact on a program's observable outcome than the structured activities of the program itself (Shadish, Cook, \& Leviton, 1991), and thus is based on the understanding that programs do not operate in a vacuum. In using CA, we conducted an initial round of data collection followed by preliminary analysis, which provided the foundation for the development of the key tool in CA, the theory of change (ToC) (Anderson, 2005). We then created the analytical framework, collected more data, and conducted another round of analysis, which informed a revised ToC. Use of the CA framework required information about the program and its outcomes, and also required incorporation of program-specific data. Table 1 outlines the standard stages of CA and how we applied each of them in this study, including deviations from standard CA procedures that were necessary for this study.

Initial data collection consisted of Internet

Table 1. Stages of Contribution Analysis (CA) and Applications in This Study of Farm Link Programs

\begin{tabular}{|c|c|c|c|}
\hline Stages of CA & Description & Function & $\begin{array}{l}\text { Application and Deviations from CA } \\
\text { in this Study }\end{array}$ \\
\hline \multirow[t]{2}{*}{$\begin{array}{l}\text { 1. Establish attribution } \\
\text { problem }\end{array}$} & $\begin{array}{l}\text { Establish the research question; } \\
\text { determine what program elements } \\
\text { will be assessed }\end{array}$ & Description & No major deviation \\
\hline & & (Research) & $\begin{array}{l}\text { Included preliminary data collection to } \\
\text { improve initial understanding of farm link } \\
\text { programs' (FLPs') operations }\end{array}$ \\
\hline \multirow[t]{2}{*}{$\begin{array}{l}\text { 2. Develop theory of } \\
\text { change (ToC) }\end{array}$} & $\begin{array}{l}\text { Create a flow diagram of how the } \\
\text { program is theoretically supposed } \\
\text { to affect change }\end{array}$ & Description & $\begin{array}{l}\text { Extrapolated from preliminary findings to } \\
\text { develop a general, cross-program ToC }\end{array}$ \\
\hline & & (Research) & $\begin{array}{l}\text { Included preliminary analysis to extrapolate } \\
\text { themes dominating the ToC }\end{array}$ \\
\hline $\begin{array}{l}\text { 3. Gather information } \\
\text { on ToC }\end{array}$ & $\begin{array}{l}\text { Data collection related to the } \\
\text { program }\end{array}$ & Research & $\begin{array}{l}\text { In this instance, content analysis and } \\
\text { further literature review relevant to themes } \\
\text { dominating the ToC }\end{array}$ \\
\hline $\begin{array}{l}\text { 4. Assemble the } \\
\text { contribution story }\end{array}$ & Assess the validity of the ToC & Analysis & $\begin{array}{l}\text { Reported the findings supporting the } \\
\text { identified themes in the ToC }\end{array}$ \\
\hline 5. Gather more evidence & $\begin{array}{l}\text { Identify research gaps and gather } \\
\text { data accordingly }\end{array}$ & Research & Did not explicitly have a separate stage \\
\hline $\begin{array}{l}\text { 6. Revise contribution } \\
\text { story }\end{array}$ & $\begin{array}{l}\text { Incorporate new data and reassess } \\
\text { its relationship to the ToC. Make } \\
\text { final conclusions in the form of a } \\
\text { statement of contribution. }\end{array}$ & Analysis & $\begin{array}{l}\text { Did not revise the contribution story. } \\
\text { Instead proposed a revised ToC with } \\
\text { stronger theoretical foundations based on } \\
\text { research findings. }\end{array}$ \\
\hline
\end{tabular}

Note: Adapted from Mayne, 2008. 
searches for U.S. farm link programs. The researchers searched Google, using the search terms 'farm link programs,' 'land link programs,' and 'farm matching programs' to identify as many programs as possible. We reviewed each program website for information about process, intention, operational history, success metrics, contact information, and other relevant documentation. We then entered the information into a spreadsheet and developed a questionnaire to address information gaps such as budgets, staffing levels, and any governmental relationships. The questionnaire also included open-ended questions.

To supplement publicly available information, we emailed participation requests to staff at 19 FLPs; 12 agreed to participate. Over a three-month period we collected data. Eight participants completed the questions in writing and submitted them by email; four chose a phone interview format. The researcher conducting the interview took notes throughout the phone interview and returned these to the participant for verification. We entered participant responses into tables and reviewed the data for significant trends and themes. We then conducted more research based on those trends and themes and used all data to produce the theory of change (ToC) (Table 2).

We developed the ToC based on what we learned about FLPs as a category during the preliminary data gathering and initial analysis described above. Table 2 reflects the resulting ToC for FLPs. Each section of the table represents a specific stage in an ideal FLP farm transfer process, with the progress of each stage depending on the success of the previous stage. This ToC outlines the ideal process flow that should occur in an FLP.

Four themes emerged from the ToC: (1) the effectiveness of FLP design and program activities; (2) the usefulness of FLP databases to meet the needs of farmers; (3) farmer motivation toward development or land preservation; and (4) trends and systemic influences on farm transfers. These themes guide the second round of data collection, providing context for the findings and structure for the contribution story (CS) (Delahais \& Toulemonde, 2012; Lemire, Nielsen, \& Dybdal, 2012), which is based on evidence collected about the themes emerging from the ToC. The CS can be described as a narrative explaining why the ToC is or is not accurate, and hence why the program is effective or ineffective. The ToC is tested by examining each theme in the context of how it affects FLPs and the land transfer process. The assumptions associated with each theme (Table 2) are challenged using literature and empirical data (interviews and/or questionnaires). This approach incorporates common practices found in other types of theory-driven evaluations, where the strength of a program is tested according to how well the components of the theory function (Mayne, 2001). Once the influence of each theme is understood, each theme can be discussed in relation to the others; how these influencing factors impact FLPs and farm transfers then can be better appreciated.

At the CS development stage, program credibility and its contribution, if any, to observed outcomes are assessed (Mayne, 2008). The CS serves to validate, question, and explain the theory of change, and includes the primary empirical data and a review of relevant academic and grey literature. Specific to this research, the creation of the CS allows flaws within FLP functioning that prevent (or limit) success to be identified. The final result of the CS is a Statement of Contribution (SoC) (Mayne, 2008), which, in this case, clearly states if and how FLPs are contributing to land transfers. Several recommendations emerged that may help FLPs mitigate some of their operational challenges.

\section{Evaluating Program 'Success'}

Determining what success means for FLPs warranted further inspection of each FLP's stated objectives. Each FLP included in this research has stated goals, which are described in Table 3 .

\section{Results and Analysis: How FLPs Affect Farm Transfers (the Contribution Story)}

The following section is the CS stage in CA. Discussing the major components of the ToC in more depth, we assess the validity of the ToC as based on evidence. To put it another way, we are answering the question, "How do the main components of the ToC contribute to the effectiveness of FLPs?" Below, we discuss the four themes drawn from the ToC in greater detail. 
Table 2. Theory of Change for a Farm Link Program

\begin{tabular}{|c|c|c|}
\hline Description & Assumptions & Risks \\
\hline \multicolumn{3}{|l|}{ Stage 1: External Conditions } \\
\hline $\begin{array}{l}\text { 1. There is no familial } \\
\text { successor }\end{array}$ & $\begin{array}{l}\text { - A nonfamily member could succeed } \\
\text { instead. }\end{array}$ & $\begin{array}{l}\text { - The typical transfer process does not favor } \\
\text { nonfamily succession. }\end{array}$ \\
\hline $\begin{array}{l}\text { 2. Farmland is at risk of being } \\
\text { sold for development }\end{array}$ & $\begin{array}{l}\text { - Farmers prioritize keeping their land in } \\
\text { production. }\end{array}$ & $\begin{array}{l}\text { - Selling farmland for development is a } \\
\text { preferable or acceptable choice. }\end{array}$ \\
\hline $\begin{array}{l}\text { 3. Farmers need help finding } \\
\text { a successor }\end{array}$ & $\begin{array}{l}\text { - FLPs can be a natural go-to place for } \\
\text { farmers seeking help with a farm } \\
\text { transfer. }\end{array}$ & $\begin{array}{l}\text { - Farmers can engage in farm transfers } \\
\text { independently. } \\
\text { - Farmers seek assistance elsewhere. } \\
\text { - Farmers do not trust nonfamily members. } \\
\text { - Farmers do not know that FLPs exist and } \\
\text { may be able to help with a farm transfer. }\end{array}$ \\
\hline $\begin{array}{l}\text { 4. Beginning farmers cannot } \\
\text { find affordable, desirable } \\
\text { farmland }\end{array}$ & $\begin{array}{l}\text { - FLPs can help bring new entrants into } \\
\text { farming. }\end{array}$ & $\begin{array}{l}\text { - Farms remain too expensive to purchase } \\
\text { despite FLP efforts, or farms do not meet } \\
\text { the criteria desired by the new entrants. }\end{array}$ \\
\hline \multicolumn{3}{|l|}{ Stage 2: Program Outputs } \\
\hline 1. Database & $\begin{array}{l}\text { - All interested parties (seller and buyer) } \\
\text { use the database effectively. }\end{array}$ & $\begin{array}{l}\text { - The database is an inappropriate tool } \\
\text { and/or is underutilized. }\end{array}$ \\
\hline $\begin{array}{l}\text { 2. Basic staff support and/or } \\
\text { facilitation }\end{array}$ & $\begin{array}{l}\text { - Enough support is given to supplement } \\
\text { the use of the database. }\end{array}$ & $\begin{array}{l}\text { - Participants need more help than is } \\
\text { provided. }\end{array}$ \\
\hline 3. Print resources & $\begin{array}{l}\text { - Print resources can provide relevant and } \\
\text { appropriate guidance for farmers. }\end{array}$ & $\begin{array}{l}\text { - Print resources are not an acceptable } \\
\text { and/or appropriate medium for farmers. }\end{array}$ \\
\hline 4. Educational opportunities & $\begin{array}{l}\text { - Workshops, etc. are useful learning tools } \\
\text { that augment FLP work. }\end{array}$ & $\begin{array}{l}\text { - Workshops do not result in knowledge } \\
\text { uptake or have limited effectiveness. }\end{array}$ \\
\hline 5. Program marketing & $\begin{array}{l}\text { - Marketing schemes are effective in } \\
\text { recruiting new and retiring farmers to the } \\
\text { FLP. }\end{array}$ & $\begin{array}{l}\text { - Marketing schemes do not draw in } \\
\text { farmers to the FLP. }\end{array}$ \\
\hline
\end{tabular}

\section{Stage 3: Immediate Outcomes}

1. Awareness of potential - Farmers have used FLP information farm buyers and sellers

\begin{tabular}{|c|c|}
\hline & $\begin{array}{l}\text { - The database has been used } \\
\text { successfully. }\end{array}$ \\
\hline $\begin{array}{l}\text { 2. Opportunities arise for } \\
\text { mentorship or lease-to-own } \\
\text { arrangements (nonsale } \\
\text { partnership) }\end{array}$ & $\begin{array}{l}\text { - A potential match has been identified. } \\
\text { - Farmers are prepared to teach and begin } \\
\text { relinquishing control. }\end{array}$ \\
\hline
\end{tabular}

\begin{tabular}{|c|c|c|}
\hline $\begin{array}{l}\text { 3. Opportunities arise to } \\
\text { negotiate a farm transfer }\end{array}$ & $\begin{array}{l}\text { - A potential match has been identified. } \\
\text { - Farmers are prepared to discuss a farm } \\
\text { transfer. } \\
\text { - Farmers have access to appropriate } \\
\text { professional assistance to help negotiate } \\
\text { a transfer. }\end{array}$ & $\begin{array}{l}\text { - Personal differences prevent a farm } \\
\text { transfer. } \\
\text { - Farmers do not have the specialized } \\
\text { knowledge or support required to arrange } \\
\text { a farm transfer. }\end{array}$ \\
\hline $\begin{array}{l}\text { 4. Better understanding of } \\
\text { farm transfer process }\end{array}$ & $\begin{array}{l}\text { - Farmers have used resources or } \\
\text { participated in workshops. }\end{array}$ & $\begin{array}{l}\text { - Farmers are not prepared to implement } \\
\text { new knowledge. }\end{array}$ \\
\hline
\end{tabular}

\section{Stage 4: Intermediate Outcomes}

- Farmers do not use FLP information and/or resources.

- The database is ineffective at initiating matches.

- Personal differences prevent a farm transfer.

- Farmers do not have the specialized knowledge or support required to arrange a nonsale partnership. nowledge or support required to arrange

Farmers have access to appropriate professional assistance to help negotiate

Farmers have used resources or

- Personal or other issues prevented arrangements from occurring.

continued
Personal differences prevent a farm 


\begin{tabular}{|c|c|c|}
\hline Description & Assumptions & Risks \\
\hline 2. Farm transfers occur & $\begin{array}{l}\text { - The FLP was helpful. } \\
\text { - Farm transfers would occur anyway. }\end{array}$ & $\begin{array}{l}\text { - Personal or other issues prevented } \\
\text { transfers from occurring. }\end{array}$ \\
\hline $\begin{array}{l}\text { 3. Retiring farmers are } \\
\text { financially secure }\end{array}$ & $\begin{array}{l}\text { - Farm transfers adequately provide } \\
\text { farmers with enough money to fund } \\
\text { retirement. }\end{array}$ & $\begin{array}{l}\text { - Farmers are not able to sell the farm for } \\
\text { enough money to live comfortably in } \\
\text { retirement. }\end{array}$ \\
\hline $\begin{array}{l}\text { 4. Agricultural production is } \\
\text { sustained in region }\end{array}$ & $\begin{array}{l}\text { - New farmers will maintain existing level } \\
\text { of production. }\end{array}$ & $\begin{array}{l}\text { - New farmers engage in smaller-scale } \\
\text { farming, possibly part-time. }\end{array}$ \\
\hline \multicolumn{3}{|l|}{ Stage 5: Final Outcomes } \\
\hline 1. Farm preservation & $\begin{array}{l}\text { - Farms are transferred to a new farming } \\
\text { generation. }\end{array}$ & $\begin{array}{l}\text { - Farms are sold for development or left } \\
\text { fallow. }\end{array}$ \\
\hline 2. Rural employment & $\begin{array}{l}\text { - The farming venture is successful and } \\
\text { able to employ staff. } \\
\text { - Spin-off industries maintain viability. }\end{array}$ & $\begin{array}{l}\text { - Farms are too small to require extra } \\
\text { staffing. } \\
\text { - Farms are unsuccessful businesses. } \\
\text { - Farms have difficulty finding qualified, } \\
\text { willing laborers. }\end{array}$ \\
\hline $\begin{array}{l}\text { 3. Farmland transferred to a } \\
\text { new generation }\end{array}$ & $\begin{array}{l}\text { - Farms are sold to people for farming } \\
\text { purposes. } \\
\text { - Farmers retire financially secure. }\end{array}$ & $\begin{array}{l}\text { - Farms are not transferred. } \\
\text { - Farms are sold to people who choose to } \\
\text { significantly downsize farming operations. }\end{array}$ \\
\hline
\end{tabular}

Table 3. Stated Objectives of Farm Link Programs (FLPs) in This Study

\begin{tabular}{|c|c|c|c|}
\hline Program & $\begin{array}{l}\text { Farm transfer as a stated } \\
\text { goal or service offered }\end{array}$ & $\begin{array}{l}\text { Farming opportunities } \\
\text { and other nontransfer } \\
\text { arrangements as a stated } \\
\text { goal or service offered }\end{array}$ & $\begin{array}{l}\text { Land protection as a } \\
\text { stated goal or function }\end{array}$ \\
\hline Virginia Farm Link Program & $x$ & $x$ & $\begin{array}{l}\text { Not explicitly, but the FLP is } \\
\text { part of the Office of } \\
\text { Farmland Preservation }\end{array}$ \\
\hline Pennsylvania Farm Link Program & $\mathrm{X}$ & $\mathrm{X}$ & $\mathrm{X}$ \\
\hline Central New Mexico LandLink & $x$ & $x$ & \\
\hline $\begin{array}{l}\text { lowa State University Beginning } \\
\text { Farmer Center: Ag Link }\end{array}$ & & $X$ & \\
\hline New York Farm Link & $x$ & $x$ & \\
\hline $\begin{array}{l}\text { Center for Rural Affairs: Land Link } \\
\text { Services (Nebraska) }\end{array}$ & $X$ & $x$ & \\
\hline iFarm Oregon & & $\mathrm{X}$ & \\
\hline Colorado Land Link & $x$ & $x$ & \\
\hline $\begin{array}{l}\text { New Entry Sustainable Farming } \\
\text { Project Farmland Matching Service } \\
\text { (Massachusetts) }\end{array}$ & & $x$ & \\
\hline New Jersey Farm Link Program & $x$ & $x$ & \\
\hline Land Link Montana & $\mathrm{X}$ & $\mathrm{X}$ & \\
\hline Ohio & & $X$ & \\
\hline
\end{tabular}


Effectiveness of FLP Design and Program Activities

Each FLP has unique characteristics, which are identified and examined to understand their impact on program outcomes. Impact is specified as the number of successful matches, transfers, and/or leases resulting from program efforts. Three FLPs stand above the rest. Since the FLP came into existence, New York Farm Link reported 75 transfers and 500 farmers receiving services related to long-term transfers; the Iowa Ag Link program reported 68 farm transfers; and iFarm Oregon reported 35 transfers, including long-term lease agreements. The other programs that reported a specific number of transfers reported fewer than 10 , while some could not provide a specific number because they did not keep such data. There were no consistent trends apparent in the data that could easily explain the differences in the number of farm transfers between programs, which indicates a need to further analyze and understand the programs at a more fundamental level.

Notably, some FLP staff stated that programs should be evaluated on their ability to help establish any type of connection with potential farmers, not just on the number of successful transfers. However, program websites still specifically identify farm transfers as an important outcome (Table 3), in addition to helping establish other farming opportunities. Given that programs were created to support land transfers, in addition to these other types of connections, ${ }^{1}$ the term 'transfer' will hereafter include sales, leases, and other forms of longer-term partnerships.

Budgets and funding. FLPs rarely operate as the sole activity or focus of an organization. When asked about the yearly budgets of FLPs, most participants could provide only an approximate dollar amount. The budgets of the surveyed FLPs range from none $e^{2}$ to over US $\$ 120,000$ per year. Most budgets were between US $\$ 15,000$ and US $\$ 50,000$ (eight out of 12); much of this money went to pay-

\footnotetext{
${ }^{1}$ Some FLP staff included any type of connection made between farmers (e.g. long-term leases, partnerships, or landshare arrangements) within their definition of 'transfer.'

${ }^{2}$ One program reported that it was operating at a loss-its organizational budget did not allocate any funds for FLP work, but the work was being done by staff anyway.
}

ing staff.

An important finding was that neither levels nor sources of funding corresponded with the number of transfers. For example, a program that reported a budget of US\$120,000 had zero matches associated with the program, while a program reporting a high number of matches had a budget of approximately US $\$ 45,000$ per year. A young program also reported a high number of matches while operating with a budget of only US $\$ 30,000$. Sources of funding - mainly from the government, university funding, and private donations - did not correspond with program success. Some programs charged a user fee to new farmers, but this was not typical. Retiring farmers were not charged a fee in any of the study programs.

Staffing. Staff levels at all programs are minimal: three programs have only one full-time staff member, and nine have only a part-time staff member. Aiming to learn from existing FLPs to design a well-functioning FLP in Montana, Hubbard (2006) considered the day-to-day role and function of staff in FLPs: "It is no surprise that these understaffed programs facilitate matches as efficiently as possible by publicizing the information and resources, hoping their participants will utilize them well" (p. 20). The energy needed to actively initiate matches is not always available to staff. However, even understaffed programs have been relatively successful, suggesting that success and funding are not necessarily related. This finding suggests that further investigation is needed to better understand the specific nature of program features that are most commonly linked to success.

Program focus. FLPs all operate on similar principles. Therefore, variations in the number of transfers may result from differences in the organizations that run FLPs, or from the influence of the other services the organization offers. ${ }^{3}$ Additional services that FLPs provide can be divided into three categories. The first is farmer education and includes business planning, educating on farming

\footnotetext{
${ }^{3}$ FLPs generally operate as one segment of an organization that offers numerous services and programs. All FLPs that participated in this research were run simultaneously alongside other programs and services offered by their respective umbrella organizations.
} 
issues, and/or providing additional educational resources to farmers. The second category of services encourages social and political engagement and includes the operation of farmers markets and development of consumer information and resources, policy formation or government lobbying, and/or rural development work. The third category relates to land issues such as preservation, conservation, and zoning.

Of the three programs that declare the most number of matches to date, two strongly focus on farmer education. The third program has some focus on education for farmers, and some on broader social and political engagement activities. None of the three are concerned explicitly with land conservation. That these three FLPs focus on education and broader social and political activities is not necessarily the cause of their relative success; other FLPs also participate in these types of programming activities, yet do not have success rates comparable to these three. Therefore, it is difficult to attribute those successes to one replicable program characteristic.

Given the small number of farm transfers made through the 12 FLPs surveyed, even including those reporting higher transfer rates, it appears that FLP transfers are responsible for only a minority of farm transfers or start-ups. According to the USDA, 291,329 new farms started between 2002 and 2007, making up about 13 percent of all farms in production during those years (USDA, 2007b). It is unclear whether these farms were transferred to family or nonfamily members, or were entirely new farming operations starting up on previously unfarmed land. The relatively small influence that FLPs have on the overall number of farm transfers raises the question of what wider issues may also be influencing low transfer rates among FLPs. This part of the CS suggests that present program designs may be inadequate to influence land transfers. As the CS is developed, a clear portrayal of what FLPs do with limited staff and financial resources will underpin the overall understanding of the potential impact of FLPs. The limited influence on farm transfers is clear, but is this the whole story? The following three sections endeavor to uncover some specific challenges that may be linked to poor outcomes for FLPs, what additional factors may need to be considered, and what modifications could be made to improve FLP success.

\section{Usefulness of FLP Databases to Meet the Needs of Farmers}

Questionnaire and interview results indicate that FLPs place a heavy emphasis on database use. Participants indicated that these databases automated much of the FLP matching process. The database set-up differs in each case, but many participants indicated that they allow automated emails or contact information to be sent to a farm seller or seeker under certain conditions. Some programs screen participants and facilitate initial contacts between parties. That FLP staff rely so heavily on databases to facilitate matches is, therefore, worth examining, as their usefulness and the level of uptake on the part of users are likely significant factors in the success of FLPs.

Participants (staff who completed the interview or questionnaire) reported significantly more farm seekers than sellers using these databases. Several participants observed that the farm seekers drive the program, as they are the more eager of the parties. Two FLPs directly encouraged retiring farmers to be the main drivers of the process by initiating contact with potential buyers. Goeller (2012) also noted a disproportionate number of farm owners (fewer) and farm seekers (more) listed in FLP databases, although it is usually free for landowners to register, while seekers often have to pay a fee. The limited use of these programs by retiring farmers signifies a potential problem. It is possible that retiring farmers are less interested in engaging with an FLP that requires submission of an online form to begin the matching process. Therefore, it may be problematic that FLPs rely so heavily on databases to facilitate matches between farmers. These issues are discussed further below.

Farmers and Internet use. The body of literature that explores how farmers use the Internet is fairly homogeneous in its observations and conclusions (Briggeman \& Whitacre, 2010; Charatsari \& Lioutas, 2013; Chiu, Cheyney, Ramirez, \& Gerr, 2015; Howell \& Habron, 2004; Stenberg \& Morehart, 2007). While most farmers do have a personal computer (Briggeman \& 
Whitacre, 2010), the scope and scale of Internet usage depend predominantly on things like farm size (Briggeman \& Whitacre, 2010; Mishra \& Park, 2005; Stenberg \& Morehart, 2007), income level, education, and age (Stenberg \& Morehart, 2007).

Computers are used fairly often for farm business-related tasks (Mishra \& Park, 2005). In the early days of the Internet, however, the rate of its regular use for daily farm business tasks was much lower than that of other businesses of similar size (Warren, 2004). Since then, the literature suggests that activities such as sourcing information, email, online banking, and purchasing and/or selling goods are minimal and not universal among farmers (Charatsari \& Lioutas, 2013; Chiu et al., 2015; Taragola \& Van Lierde, 2010). This lack of use is not due to limited rural access: by 2011 , about 60 percent of rural residents had access to high speed Internet, compared to 70 percent of urban residents (U.S. Department of Commerce, 2011). Although the rate of farmer Internet use is increasing (USDA, 2013), rural farmers still lag behind those in other sectors (Khanel \& Mishra, 2013). Limited Internet use among farmers is not necessarily a problem, unless the Internet is used as a "default medium for knowledge transfer, commerce, etc." (Warren, 2004, p. 380), thus leaving some farmers at a disadvantage.

There are legitimate reasons why Internet adoption has been slower among aging farmers; FLPs need to understand these issues. "Older operators are less likely to adopt the internet" (Briggeman \& Whitacre, 2010, p. 573). Studies consistently show a clear negative correlation between age and Internet use in farmer business (Howell \& Habron, 2004; Stenberg \& Morehart, 2007), and a 2015 study by Chiu et al. investigating where farmers got health and safety information shows the Internet to be a least trusted source of information among farmers of all ages. While farmers may have computers and Internet access, they may not use them as a business tool or a source for business-related information (Chiu et al., 2015; Stenberg \& Morehart, 2007). Varble, Secchi, and Druschke (2016) suggest that those farmers who do use the Internet more extensively — such as for business communications and sourcing information-would be considered 'innovators,' suggesting that the use of the Internet for these purposes is not the norm for farmers. Such conditions provide plausible explanation for why the FLP databases are sparsely populated with farm owners.

Personal security on the Internet. Older farmers are concerned that personal information will not remain secure on the Internet (Briggeman \& Whitacre, 2010; Warren, 2004), more so than other population groups (Stenberg \& Morehart, 2007). FLP staff have noted this concern and emphasized the need to take extra care to protect contact information stored in FLP databases to alleviate farmers' concerns about security. FLPs need to improve farmer confidence that their personal information is secure.

\section{Perceived usefulness of the Internet.} Hubona and Geitz (1997) suggest that any type of technology adoption process requires the potential adopter first to perceive the technology as useful and easy to use. This positive (or negative) perception determines adopter attitude toward the technology, which in turn drives his or her intention to use it (or not). Research suggests that farmers often are not aware of how they can benefit from using the Internet (Taragola \& Van Lierde, 2010), and their "lack of perceived need for the internet" (Briggeman \& Whitacre, 2010, p. 581) will prevent its use. In addition, "farmers are more skeptical of the quality of the internet as compared with that of face-to-face information diffusion" (Charatsari \& Lioutas, 2013, p. 122), and believe that the Internet is not actually a suitable replacement for traditional methods of conveying information to farmers (Ballantyne, 2009).

In the case of FLPs, the online database and automated functions such as email have replaced the human-to-human interaction and information exchange that are more comfortable and familiar to farmers. Interestingly, various interviewees were aware of this issue and suggested that farmers still make connections primarily via their own networks of friends, family, and acquaintances. Interviewees accepted that using a program like an FLP is not a typical way to sell a piece of property, and that despite the best efforts of FLPs, farmers wishing to sell their land will look to more traditional avenues (e.g., lawyers and real estate agents). To be more 
successful, FLPs may need to invest in more traditional communication methods including, ideally, more face-to-face contact. One opportunity could be to arrange networking sessions in hub locations that involve both buyers and sellers and a form of facilitated interaction. Other industrial sectors seeking to development relationships between disparate actors have used this "speed-dating" approach with considerable success (Liu, Adams, Cote, Geng, \& $\mathrm{Li}, 2016)$, thus demonstrating the potential for such events.

\section{Farmer Motivations Concerning Development and Land Preservation}

Data analyses suggest that FLPs assume that farmers prefer their farmland to be kept in production and that it is only the difficulty of transferring the farm that prevents it from being used for continued agricultural production. These assumptions are simplistic, as complex economic, personal, and geographic factors influence farmers' decisions about the future use of their farmland. Farmland is a financial asset and can be a source of income during retirement; it is a potential home during retirement; it is a place filled with sentimental value for many farmers (Mishra, El-Osta, \& Johnson, 2004); and in many cases, it is a legacy (Duffy, 2011). The services FLPS offer may not address the reasons a farmer might decide to sell farmland.

Financial considerations. Farmers considering selling land take into account things like their health, age, children's interest in farming, opportunity for nonfarm occupation, and desire to relocate (White, 1998). Financial needs strongly motivate farmers' decisions about their land; in many cases, farmer financial needs are better served by selling the land at development prices (Zollinger \& Krannich, 2002) than by passing it on to subsequent generations (Pitts et al., 2009). A farmer facing unfavorable farming conditions, such as sprawl, may consider transferring to a family member who has expressed interest in taking over the family farm, but not to a nonfamily member (Zollinger \& Krannich, 2002) because "farmers may feel that the child who has been planning to take over the farming operation should have the right to attempt farming operations in the current area or sell the operation for non-agricultural land use" (Zollinger \& Krannich, 2002, p. 459). If there is no family member to take over the farm, however, the farmer may simply sell the land for nonagricultural uses (Zollinger \& Krannich, 2002) or hold onto the land as long as possible (Duffy, 2011). For FLPs, this means that some decisions regarding farm sales have little to do with the farmer's ability to find a buyer. These common tendencies of retiring farmers may prevent farmland from becoming available to new farmers, thus limiting the rate of possible transfers.

If the farm owner is interested in selling to a new farmer, pricing can make selling difficult. Retiring farmers seek to profit enough to make retirement comfortable, but to keep the land undeveloped and in production, the asking price must be affordable for the new farmer (Pitts et al., 2009). Without a family successor, farmers may feel it is not worth the effort to find a successor if they believe market, community, or geographical conditions are poor. Alternatively, a farmer may simply not be willing to put the farm on the market for a nonfamily member to purchase (Duffy, 2011). This presents a question of convenience: when faced with various options, will a farmer opt for the simplest type of sale?

Sentimental attachment to family farmland. Money may not be the only important factor in the decision to sell farmland. Farmers can have a sentimental attachment to their land and feel that it is part of their identity (Gasson \& Errington, 1993). For some, the possibility that their children will not take over the farm may produce a deep sense of loss (Dessein \& Nevens, 2007). Their attachment to the land and their history on it can affect how likely they are to try to keep the land in production (Kuehne, 2013). Because the link between how farmers define their identity and the decisions they make about their land is poorly understood (McGuire, Morton \& Cast, 2013) it raises the possibility that some farmers would avoid succession planning as a self-identity preservation tactic; that is, being unable to accept that their farm will, or should, be transferred, a farmer may delay developing a succession plan and thus keep their farming identity intact. What is known, however, is that farmers who choose to develop succession plans do have a desire to see their land continue to 
be used for agriculture (Darnhofer, 2010; Higby, Ruhf, \& Woloschuk, 2004). The absence of succession planning will likely limit the likelihood that farmers will be able to transfer their farms, thus undermining the possibility of its continued use as farmland (Pitts et al., 2009).

Urbanization considerations. Urban and suburban encroachment results in decreased output and productivity for remaining farms and, over time, a higher amount of idle farmland (Daniels \& Bowers, 1997; Thompson \& Prokopy, 2009). In a phenomenon known as 'impermanence syndrome,' when farmers assume that their land will be developed eventually, they reduce their investments in soil health and their production capacity wanes (Daniels \& Bowers, 1997; Olson, 1999). Farmers adapt to urban encroachment with 'negative adaptation'; they attempt to maintain business as usual, but eventually they close the farm business (Johnston \& Bryant, 1987; Sharp \& Smith, 2003). External pressures, then, further affect the circumstances under which farmers operate and make decisions about farmland preservation or development. If an FLP works under the expectation that farmers want to keep their land in production at all costs, that FLP may be on the path to failure.

\section{Trends and Systemic Influences on Farm Transfers}

Succession process. Arranging transfers with nonfamily members is a difficult, emotionally wrought endeavor; a farmer may not be willing or able to bring an unknown person into their operation as easily as they might bring in a family member. This is not to suggest that transitions with family members are simple; they too can be difficult. A farmer's attachment toward his or her farmland makes it difficult to break ties to the land upon retirement (Mishra, Johnson, \& Morehart, 2003). Relinquishing control may also be financially worrisome for farmers who need to generate retirement income from farm assets (Keating \& Munro, 1989). Any of these issues can hinder the transition process (O'Neill, Komar, Brumfield, \& Mickel, 2010).

Much of the motivation to modify a farm business is linked to preparations undertaken to pass on the farm within a family (Inwood et al., 2013). Keating and Munro (1989) describe how younger farmers prepare to take over a farm by engaging in activities of increasing responsibility in the following order: general farm work; livestock care; production management; marketing management; financial management; land holdings; and equipment holdings. Any good succession process typically begins long before a farmer sells the farm to a successor because the mere expectation of a successor (or none) can affect the succession process (Pitts et al., 2009). Farmers who intend to pass on their business are more likely to make decisions aimed for longer-term growth (Gasson et al., 1988; Stiglbauer \& Weiss, 1999). Potter and Lobley (1992) describe this phenomenon as 'the successor effect.'

Larger farms are more likely to have a family successor than smaller farms (Glauben, Tietje, \& Weiss, 2002). Smaller family farms may be at a greater risk of experiencing the impermanence syndrome. Furthermore, relatively few farmers have concrete retirement plans, intending instead to use their farms for income once they retire (Duffy, 2011). This finding is congruent with other studies that indicate that as farmers become semiretired, they expect to be able to continue drawing income from the farm (Gasson, Errington, \& Tranter, 1998; Keating \& Munro, 1989;

Kirkpatrick, 2013). Such farmers tend to adopt static management practices or disinvest in the farm, selling off some land and assets with the intention of continuing to use the remaining land to finance their retirement (Inwood \& Sharp, 2012).

Leasing as a potential farm transfer option. Leasing can be a more affordable and gradual way for new farmers to begin their farm business or gain valuable experience (Hubbard, 2006). Also, some farmers wanting to sell land have more to sell than is typical for new farmers to purchase. Leasing may allow new farmers to take partial control of the land, which can offer alternative retirement financing options for the landowning farmer.

However, leasing or renting land may impinge on the long-term productivity of the land. Various tax structures in the U.S. incentivize farmers to rent their land to fund their retirement rather than sell it, which may mean that the farm is not as well managed and productive as it would be if it were owned (Slack, 2013), possibly because tenant 
farmers are likely to take few big risks in their farming operations (Fukunaga \& Huffman, 2009). Leasing arrangements offer no guarantee that production would continue after the death of the landowner (Slack, 2013). Furthermore, farmland available to rent may not be suitable for new farmers; if the land available is excess land without a house or other buildings, it is more likely that an established neighboring farmer will lease it. The more farmland that is rented in such scenarios limits the land available for young farmers to purchase (Ilbery, Ingram, Kirwan, Maye \& Prince, 2012).

Given the limitations on the viability of leasing land on a long-term basis, FLPs should nurture farmers wanting to enter such arrangements, while being mindful that many new farmers choose to own land (Shute et al., 2011). As a short-term option, leasing may be acceptable, but as a longterm strategy, ownership may be a more successful option.

New farmers. Understanding the behavior, motivations, situations, and needs of aspiring farmers is important when trying to create a more favorable farm transfer environment. New farmers are not all young; in the U.S., their average age in 2007 was 48 (USDA, 2007b), with approximately one-third over 55 (Ahearn \& Newton, 2009; Inwood et al., 2013). New farmers are unevenly distributed across the U.S.; concentrations range from 10 percent or less in a county to as much as 50 (Ahearn \& Newton, 2009). New farmers tend to start out with smaller farming operations; "entry rates decline as farm size grows" (Ahearn \& Newton, 2009, p. 20). The average size of new farms in 2007 was 201 acres (81 hectares), less than half the average farm size of 418 acres or 169 hectares (USDA, 2007b). New farmers may want to start with smaller farms due to the challenges of accessing financing, resources, and information (Clark, Inwood, \& Sharp, 2016). Furthermore, as beginning farmers are likely to have off-farm employment (as 80\% do) (Inwood et al., 2013; USDA, 2007c), there is less need to make money solely from farming, lessening the need to purchase a large land parcel. The connection between age and off-farm employment is notable: new farmers may enter farming later in life after working in other careers and saving for a farm purchase. They may also continue working in other jobs; new farmers are often drawn to the farming lifestyle as opposed to a farming career (Ahearn \& Newton, 2009). In fact, in the 2007 U.S. census, 32 percent of new farmers ${ }^{4}$ did not report any production on their land at all (Ahearn \& Newton, 2009). Understanding that new farmers are not always young, are likely to seek out smaller farms, and may choose to be employed off the farm can provide insight that may support program innovations within FLPs to alleviate the potential difficulties in transferring land caused by these realities.

Incongruent needs: retiring vs. new farmers. Beginning farmers have needs that are not aligned with those of established farmers. One problem is that established farmers have much more land and a larger farm business than a beginning farmer can often afford or manage (Inwood et al., 2013). New farmers face high startup costs (Ahearn \& Newton, 2009), and as land values increase, it becomes even more difficult to buy large parcels of farmland (Lobley \& Baker, 2012), which may not even suit the needs of new farmers (Ahern \& Newton, 2009).

Importance of social networks. Existing social networks create both opportunities and barriers. Strong social networks are important for beginning farmers, yet many — when they are from outside a given agricultural community-experience social isolation in communities where they attempt to begin their farming career (Mailfert, 2007). Such networks facilitate farm acquisition, since it is more likely for farms to be exchanged between friends, family members, and neighbors (Robison, Myers, \& Siles, 2002, p. 45). Furthermore, farmland typically sells at a lower price when the seller knows the buyer, demonstrating that "relationships do matter in farmland exchange" (Robison et al., 2002, p. 57). New farmers who want to rent farmland may find themselves competing against established area farmers who want to

\footnotetext{
${ }^{4}$ The USDA defines 'beginning farmer' as someone operating a farm for 10 years or less regardless of how much income they derive from their farm. These farmers may not have a goal of producing agricultural commodities and may simply be living on the farmland (Ahearn \& Newton, 2009).
} 
expand their business (Ingram \& Kirwan, 2011). Accordingly, new farmers wanting to make shortterm arrangements with an established farmer to gain experience may find it difficult to do so.

Study participants emphasized that they are as interested in helping farmers find opportunities as they are in facilitating farm sales. Recalling what was discussed earlier about incorrect assumptions about how farmers value their farmland, the understanding that farmers have strong social bonds can be an advantage to FLPs. We suggest that time and energy spent building social networks between retiring and new farmers could result in more favorable outcomes later in terms of farm transfers.

\section{Recap of FLP Challenges}

Table 4 summarizes the challenges FLPs identified during this research (Column 1), and possible solutions that we have proposed (Column 2). Acknowledging and addressing challenges, problems, and common mistakes of FLPs are foundational in developing a more effective FLP. The

Table 4. FLPs: Existing Problems and Potential Solutions

\begin{tabular}{|c|c|c|}
\hline & Problem & Solution \\
\hline \multirow{6}{*}{ 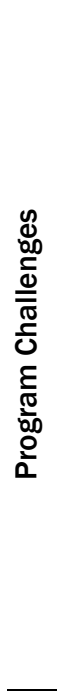 } & $\begin{array}{l}\text { Heavy reliance on internet to recruit } \\
\text { farmers with land }\end{array}$ & $\begin{array}{l}\text { - Face-to-face recruitment } \\
\text { - Hard copy/mail-in registrations for program } \\
\text { - Staff to facilitate matches more actively } \\
\text { - Educate farmers on Internet use and online security }\end{array}$ \\
\hline & Unclear long-term goals & - Clarify long-term goals and develop viable strategy \\
\hline & $\begin{array}{l}\text { Short-term goals do not match long-term } \\
\text { strategy }\end{array}$ & $\begin{array}{l}\text { Determine whether other initiatives should be undertaken alongside } \\
\text { FLP (lobby for better policies and/or legislation, find secure funding, } \\
\text { build and strengthen farming networks, etc.) }\end{array}$ \\
\hline & Understaffed programs & $\begin{array}{l}\text { - Better align staffing with the program tasks and actions known to have } \\
\text { the greatest influence to optimize staff impact } \\
\text { - Where possible, hire more staff }\end{array}$ \\
\hline & $\begin{array}{l}\text { Unstable funding leads to lack of long- } \\
\text { term planning }\end{array}$ & - Secure long-term fundinga \\
\hline & $\begin{array}{l}\text { Not connected to ready and affordable } \\
\text { specialists on farm transitions (e.g., } \\
\text { lawyers, real estate agents, etc.) }\end{array}$ & $\begin{array}{l}\text { - Establish connections with professionals willing to support and/or } \\
\text { facilitate major parts of the farm transition, possibly including } \\
\text { counselors to help with personal stresses experienced by farmers }\end{array}$ \\
\hline \multirow{7}{*}{ 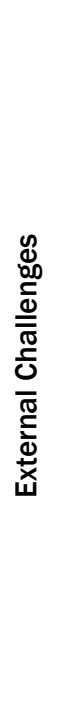 } & Mismatched farm size to sell, rent, or buy & $\begin{array}{l}\text { - Enhance cooperative farming opportunities to create more flexible } \\
\text { options }\end{array}$ \\
\hline & $\begin{array}{l}\text { Farmers with land renting to established } \\
\text { farmers rather than to beginning farmers }\end{array}$ & - Create and foster strong mentorship programs and farmer networks \\
\hline & $\begin{array}{l}\text { Farms are too expensive for beginning } \\
\text { farmers }\end{array}$ & $\begin{array}{l}\text { - Work with alternative or innovative financing mechanisms to create } \\
\text { better financing options for beginning farmers }\end{array}$ \\
\hline & Weak networks for beginning farmers & $\begin{array}{l}\text { - Create more mentorship opportunities, farm community integration } \\
\text { programs, and networking opportunities for new and established } \\
\text { farmers }\end{array}$ \\
\hline & $\begin{array}{l}\text { Farmers often unprepared for farm } \\
\text { transfers, or succession plans made too } \\
\text { late to maintain viable farm business }\end{array}$ & $\begin{array}{l}\text { - Provide education on succession planning for farmers at all ages and } \\
\text { stages of their farming career }\end{array}$ \\
\hline & $\begin{array}{l}\text { Lack of trust between farmers selling and } \\
\text { new farmers buying land }\end{array}$ & $\begin{array}{l}\text { - Create more opportunities for incorporating new farmers into the } \\
\text { farming world } \\
\text { - Provide networking opportunities }\end{array}$ \\
\hline & $\begin{array}{l}\text { Family farms may be sold after each } \\
\text { generation }\end{array}$ & - Create a culture of farm succession planning for non-family members \\
\hline
\end{tabular}

a The difficulty of this task is fully recognized, but it must be stated here because adequate funding is imperative to the long-term planning and implementation of a well-functioning FLP. 
table has been divided into two sections: the challenges specific to how the programs operate (Program Challenges), and external challenges (External Challenges) that are more systemic and institutionalized within the agriculture sector. By understanding the problems with current FLPs, one can integrate mechanisms and strategies into newly developed programs to address such issues.

The revised ToC (Table 5) draws from the evaluation work completed here. From the development of the CS, it became clear that the original ToC is flawed; that is, program activities seem to be based on flawed assumptions. Therefore, the ToC was revised to better reflect conditions that may ensure the success of an FLP. The hope is that this new, more robust ToC can be used to create a new FLP or to update an existing FLP's programming. Stage 1 of Table 5 focuses on an FLP's dayto-day activities, the reasoning behind them, and possible risks that may prevent success. If the actions taken by the FLP as outlined in Stage 1 are successful, certain short-term outcomes would be expected. Stage 2 outlines immediate (short-term) expected outcomes. Stage 3 focuses on indirect (long-term) outcomes that may result from the program outputs (Stage 1) and the short-term outcomes (Stage 2). This revised ToC can serve as either a starting point for a new FLP or a point of evaluation for existing FLPs.

\section{Discussion: Contribution of FLPs}

Stages four through six of CA focus on building the contribution story of FLPs. The information needed to build the CS is presented in the previous sections. The final task in the CS is to make a statement of contribution (SoC), a short summary of how well the programs meet - or do not meetintended outcomes (Mayne, 2001). In the context of this research, the following statement is offered: FLPs are well-intentioned programs aimed at addressing real concerns in the farming community, but in their current form are not able to effectively facilitate large numbers of farm transfers.

FLPs have not demonstrated their ability to successfully, reliably, and routinely facilitate farm transfers on a large scale. Although this is a reasonable metric of success, FLP staff have often been reticent to define success in this way. This would suggest a recognition of their limited influence. While their efforts have not been entirely in vain, one must consider the steady rate of farmland loss each year, the number of farm sales that occur outside an FLP program, and the limited influence FLPs have had facilitating these transfers. It remains unclear if FLPs actually did facilitate successful matches, thereby preventing the sale of farmland for development, or if FLPs simply capitalized on a farmer's commitment to succession and provided an additional avenue to do so.

The crucial challenges FLPs have yet to face include reliance on the Internet for initiating farmer connections, despite evidence of its lack of effectiveness; a small staff complement, who are unable to provide legal, financial, and professional assistance required by farmers; limited resources and mechanisms for bridging the gap between new farmer financial capacity and the price of farmland; weak networks for new farmers and FLPs' limited ability to improve them; and a mismatch in the requirements of new and retiring farmers. If they are to be relevant in the longer term, FLPs need to carefully assess each of these challenges and determine their capacity to overcome them. Importantly, challenges must be addressed simultaneously—as they are essential components of a farm transferand work synergistically. FLPs should consider several improvements to their structure, programming, and skill set. While these recommendations are not necessarily a component of CA, our research has resulted in several recommendations that may help mitigate problems experiences by FLPs.

\section{Strengthening Networks}

FLPs should not operate in isolation; many FLPs do function within an organization that can provide education for farmers and consumers, networking opportunities, professional development, and so forth. Networks are vital for farmers, and new farmers especially. FLPs should consider expanding networks by partnering with other organizations-connecting with local, state, or even the federal government, education centers and universities, financial institutions, or real estate and legal professionals. Having strong support from these types of institutions can strengthen the 


\section{Table 5. Revised Theory of Change for a Farm Link Program (FLP)}

\begin{tabular}{|c|c|c|}
\hline Description/Activity & Assumption & Risk \\
\hline \multicolumn{3}{|c|}{ Stage 1: Program Outputs: Specific activities done by FLP and day-to-day program activities } \\
\hline $\begin{array}{l}\text { Heavy focus on succession plan- } \\
\text { ning education for all farmers: } \\
\text { hold workshops, provide } \\
\text { literature, etc. }\end{array}$ & $\begin{array}{l}\text { Succession planning is essential to foster } \\
\text { farm transfers and is the foundation of } \\
\text { successful farm transfers. }\end{array}$ & $\begin{array}{l}\text { Succession planning has not occurred } \\
\text { yet; farmers do not prepare for the } \\
\text { emotional and/or social challenges that } \\
\text { accompany farm transfers. }\end{array}$ \\
\hline $\begin{array}{l}\text { Personal outreach by staff to all } \\
\text { farmers approaching retirement } \\
\text { age without a successor. }\end{array}$ & $\begin{array}{l}\text { Personal connections are the most } \\
\text { effective way of bringing retiring farmers } \\
\text { into the program. }\end{array}$ & $\begin{array}{l}\text { Farmers are not interested or are } \\
\text { skeptical of the service. }\end{array}$ \\
\hline $\begin{array}{l}\text { Offer Internet database as a } \\
\text { supplementary tool, targeted to } \\
\text { young farmers. }\end{array}$ & $\begin{array}{l}\text { Young farmers are more likely to use the } \\
\text { Internet to find information and connect } \\
\text { to farming opportunities and } \\
\text { communities. }\end{array}$ & $\begin{array}{l}\text { Relying on the database to attract new } \\
\text { farmers may not be the most effective } \\
\text { form of engagement. }\end{array}$ \\
\hline $\begin{array}{l}\text { Partner with and utilize farm tran- } \\
\text { sition specialists (e.g., lawyers, } \\
\text { real estate agents) to facilitate } \\
\text { farm transfers. }\end{array}$ & $\begin{array}{l}\text { This will help the FLP meet specific needs } \\
\text { of farmers who will use the program. }\end{array}$ & $\begin{array}{l}\text { Could be difficult to bring in these } \\
\text { partners on a reliable basis. }\end{array}$ \\
\hline $\begin{array}{l}\text { Connect young farmers with loan } \\
\text { and financing opportunities. }\end{array}$ & $\begin{array}{l}\text { The FLP should help with all aspects of } \\
\text { farm transfers, including helping young } \\
\text { farmers secure funding. }\end{array}$ & $\begin{array}{l}\text { There are funding bodies in place, and it } \\
\text { may not be possible for the FLP to offer } \\
\text { more funding. }\end{array}$ \\
\hline $\begin{array}{l}\text { Host localized networking oppor- } \\
\text { tunities, e.g., farm tours or work } \\
\text { parties. }\end{array}$ & $\begin{array}{l}\text { This can help broaden a farmer's network, } \\
\text { provide opportunities for older and young } \\
\text { or new farmers to mingle, and establish } \\
\text { trust. }\end{array}$ & $\begin{array}{l}\text { Farmers may not want to participate in } \\
\text { these types of events and will still choose } \\
\text { to develop their own networks. }\end{array}$ \\
\hline \multicolumn{3}{|l|}{ Stage 2: Immediate Outcomes } \\
\hline $\begin{array}{l}\text { Farmers are better prepared for } \\
\text { retirement and succession. }\end{array}$ & $\begin{array}{l}\text { The information given is appropriate and } \\
\text { applicable. }\end{array}$ & $\begin{array}{l}\text { Improper planning and lack of education } \\
\text { is not what prevents farmers from } \\
\text { selling their land to a new farmer. }\end{array}$ \\
\hline $\begin{array}{l}\text { Stronger networks in the farming } \\
\text { community. }\end{array}$ & $\begin{array}{l}\text { Strong networks build trust between } \\
\text { farming generations. }\end{array}$ & $\begin{array}{l}\text { Trust and confidence in the abilities of } \\
\text { new farmers may not actually improve } \\
\text { chances for succession. }\end{array}$ \\
\hline $\begin{array}{l}\text { Begin matching retiring and new } \\
\text { farmers. }\end{array}$ & $\begin{array}{l}\text { Farmers are interested in using the FLP } \\
\text { services. }\end{array}$ & $\begin{array}{l}\text { Farmers are not served by the FLP and } \\
\text { choose not to participate. }\end{array}$ \\
\hline \multicolumn{3}{|c|}{ Stage 3: Indirect (Long-term) Outcomes } \\
\hline $\begin{array}{l}\text { Farm transfers are arranged and } \\
\text { completed. }\end{array}$ & $\begin{array}{l}\text { FLP was able to meet the needs of } \\
\text { farmers to facilitate a farm transfer. }\end{array}$ & $\begin{array}{l}\text { Farmers still have difficulty transferring } \\
\text { their farm to a nonfamily member. }\end{array}$ \\
\hline Farms continue to be productive. & $\begin{array}{l}\text { New owners continue to use the land for } \\
\text { food production. }\end{array}$ & $\begin{array}{l}\text { Farms turn into hobby farms and are not } \\
\text { especially productive. }\end{array}$ \\
\hline $\begin{array}{l}\text { Farm transfers become a regular } \\
\text { part of farm businesses. }\end{array}$ & $\begin{array}{l}\text { Family succession decreases and farmers } \\
\text { need to sell the farm upon retirement. }\end{array}$ & $\begin{array}{l}\text { Farm transfers to nonfamily members } \\
\text { remain difficult and rare. }\end{array}$ \\
\hline $\begin{array}{l}\text { Farmland is protected from urban } \\
\text { development. }\end{array}$ & $\begin{array}{l}\text { Farmers will choose to keep their land in } \\
\text { farming if they can. }\end{array}$ & $\begin{array}{l}\text { Farmers are able to financially benefit } \\
\text { from selling their land for development } \\
\text { and prefer this option to fund their } \\
\text { retirement. }\end{array}$ \\
\hline
\end{tabular}

resources that FLPs can offer.

By affiliating with other farming organizations, FLPs can gain credibility with potential land sellers. Relying on landowning farmers to register online to list their land has not proven successful; FLPs need to find other ways to foster participation. More direct interaction may help farmers recognize the benefits and opportunities of participating in FLP 
programming and the transfer process. In addition, implementing integrated networking strategies that have been utilized in other sectors is important; farmers are a heterogeneous, disparate group, and looking to other sectors that have integrated such network development successfully could be tremendously helpful. Of particular interest could be industrial-sector network development strategies that seek to bring together small and medium-sized enterprises and industrial players who have potential resources to exchange but no other obvious grounds for interaction.

\section{Normalize Succession Planning}

As the number of farmers seeking to retire increases and land values continue to rise, FLPs will need to strengthen their programming if they are to play a relevant role in supporting sustainable succession of farm land in the U.S. As noted, FLPs need to improve opportunities for face-to-face networking and facilitating more meaningful interaction. This will either require more staff and funding (a challenge), or more innovative approaches to facilitating interaction between land sellers and seekers. Family transfers are declining, so it is essential for FLPs and related initiatives to find ways to meaningfully connect with farmers and actively encourage them to think and plan for succession early on.

\section{Improve Financial Support}

Funding a new farming venture is onerous; FLPs can expand financial support services and secure avenues that would allow them to offer financial assistance to new farmers. Although California FarmLink did not participate in this research, ${ }^{5}$ publicly available information suggests that its program structure allows it to facilitate financial support for new farmers. It has more staff than any of the FLPs that participated in this study, and its staff becomes very involved in the transfer process. California FarmLink also can offer new farmers loans of up to US $\$ 25,000$ and has connected with alternative financing sources to provide further assistance (California FarmLink, 2013). It has reportedly assisted over 3,000 farm businesses and

\footnotetext{
${ }^{5}$ They were, however, invited to do so.
}

has successfully arranged 125 farm leases and related partnerships (California FarmLink, n.d.). Its hands-on, practical approach appears to demonstrate an understanding of the main challenges linked to farm transfers. Ideally, FLPs serve as a distribution broker for resources such as start-up grants or funding that supports new farmers, thus helping new farmers to find both land and funding.

\section{Evaluation Processes}

Regular and systematic evaluation of FLP activities is essential. Part of the evaluation should be to ensure that the FLP's goals are articulated clearly and specifically. Understanding the links between initiatives and the FLP's goals, internal capacity to deliver on initiatives, and ultimate success of the transfer program should help inform any changes or improvements the FLP may need. Those working in FLPs must also recognize outside contributing factors that influence farm transfers, and those factors must be accounted for in FLP programming as much as possible. CA could serve as a useful framework for individual, ongoing FLP evaluations.

\section{Innovative Stakeholder Engagement}

FLPs are not the only operations that face challenges engaging with their stakeholder groups. During their program evaluations, it is imperative that FLPs seek out innovative mechanisms used to connect disparate groups, not only those within other farming related organizations, but also those in different sectors.

\section{Conclusions}

While FLPs have the potential to help farmers find reasonable and appropriate farmland arrangements suitable to their own personal circumstances, several FLPs involved in this study have yet to experience much success, in terms of transfer numbers or in facilitating other types of land arrangements. More successful programs have some of the essential criteria for success in place, although each program is strong in different areas. Common strengths include having established networks within farm communities, spending time recruiting landowners, and offering legal and financial support. This research has helped to position the work 
of FLPs within a broader context, leading to a better understanding of the contribution FLPs can make toward preserving farmland, helping farmers retire with financial security, and assisting new farmers with start-up costs and access to land. FLPs need to clearly understand and articulate their own internal goals and limitations in order to be a useful resource, and they should monitor and evaluate their program offerings. Providing an Internet database and a website is not enough to encourage farm transfers. More work needs to focus on the actual development and strengthening of networks, particularly between other organizations supporting successful farm transfers, and between potential land sellers and seekers.

This research contributes to the body of knowledge associated with FLP effectiveness, which currently suffers from a dearth of material. In addition, we have found $\mathrm{CA}$ to be a useful framework for future FLP research because it requires analysis that incorporates many outside factors, from tax structures to attitudes and beliefs about farmland. Each factor is worthy of specific study in the context of farm transfers and FLPs. A fuller understanding of the changing trends in farm ownership and the opportunities and challenges presented is also an important research area.

It was beyond the scope of this research to engage directly with farmers who have used FLP services, but further research could focus on whether FLPs met their needs and expectations, and thus identify more specific criteria for success for FLPs. Additionally, it would be useful to research the experiences of farmers who have sold their farmland for development; their stories could inform ways to mitigate the loss of farmland to urban development.

Understanding the role of FLPs can be an important component in the discussion about farmland preservation and how to better support transitioning farmers. To date, FLP programs have met with limited success, but with specific changes, FLPs could play an important role in keeping farmland in production. This study has used an evaluation framework for the first time to assess FLPs' effectiveness in facilitating farm transfers. This research has made a strong case for FLPs to include formal evaluations regularly as a means to find practical ways to improve on program offerings. As external conditions change and more farmers find they have difficulty transferring their farms, FLPs will need to change and adapt as well. Knowing where change is necessary in their program operations can be found through rigorous evaluation, thus improving prospects for FLP success.

\section{References}

Ahearn, M. C., \& Newton, D. J. (2009). Beginning farmers and ranchers. Economic Information Bulletin, 53. https://dx.doi.org/10.2139/ssrn.1408234

Amshoff, S., \& Reed, D. (2005). Health, work, and safety of farmers ages 50 and older. Geriatric Nursing, 26(5), 304-308. http://dx.doi.org/10.1016/j.gerinurse.2005.08.008

Anderson, A. (2005). An introduction to theory of change. The Evaluation Exchange, 11(2). Retrieved from http://www.hfrp.org/evaluation/theevaluation-exchange/issue-archive/evaluationmethodology/an-introduction-to-theory-of-change

Ball, A. L., \& Wiley, A. (2005). The aspirations of farm parents and pre-adolescent children for generational succession of the family farm. Journal of Agricultural Education, 46(2), 36-46. http://www.jaeonline.org/index.php/back-issues/

Ballantyne, P. (2009). Accessing, sharing and communicating agricultural information for development: Emerging trends and issues. Information Development, 25(4), 260-271. http://dx.doi.org/10.1177/0266666909351634

Briggeman, B. C., \& Whitacre, B. E. (2010). Farming and the Internet: Reasons for non-use. Agricultural and Resource Economics Review, 39(3), 571-584. https://dx.doi.org/10.1017/S1068280500007528

California FarmLink. (n.d.). About us. Retrieved in February 2013 from http://www.californiafarmlink.org/about-us

Charatsari, C., \& Lioutas, E. D. (2013). Of mice and men: When face-to-face agricultural information is replaced by a mouse click. Journal of Agricultural \& Food Information, 14(2), 103-131. https://dx.doi.org/10.1080/10496505.2013.774276

Chiu, S., Cheyney, M., Ramirez, M., \& Gerr, F. (2015). Where do agricultural producers get safety and health information? Journal of Agromedicine, 20(3), 265-272. https://dx.doi.org/10.1080/1059924X. 2015.1045156 
Clark, J. K., Inwood, S., \& Sharp, J. S. (2016). Local food systems: The birth of new farmers and the demise of the family farm? In N. Reid, J. Gatrell, \& P. Ross. (Eds.), Local food systems in old industrial regions: Concepts, spatial context, and local practices (pp. 131-145). Abingdon, UK \& New York: Routledge.

Daniels, T. L., \& Bowers, D. (1997). Holding our ground: Protecting America's farms and farmland. Washington, DC: Island Press.

Darnhofer, I. (2010). Strategies of family farms to strengthen their resilience. Environmental Policy and Governance, 20(4), 212-222. http://dx.doi.org/10.1002/eet.547

Delahais, T., \& Toulemonde, J. (2012). Applying contribution analysis: Lessons from five years of practice. Evaluation, 18(3), 281-293. http://dx.doi.org/10.1177/1356389012450810

Dessein, J., \& Nevens, F. (2007). "I'm sad to be glad". An analysis of farmers' pride in Flanders. Sociologia Ruralis, 47(3), 273-292. http://dx.doi.org/ 10.1111/j.1467-9523.2007.00437.x

Duffy, M. (2011). The current situation on farmland values and ownership. Choices: The Magazine of Food, Farm, and Resource Issues, 26(2). Retrieved from http://choicesmagazine.org/choicesmagazine/theme-articles/farmland-values/thecurrent-situation-on-farmland-values-andownership\#sthash.iyEhMn8k.dpuf

Farmland Information Center (2013). 2010 Natural Resources Inventory. Washington, DC: USDA Natural Resources Conservation Service \& American Farmland Trust. Retrieved from http://www.farmlandinfo.org/2010-nationalresources-inventory

Fukunaga, K., \& Huffman, W. E. (2009). The role of risk and transaction costs in contract design: Evidence from farmland lease contracts in U.S. agriculture. American Journal of Agricultural Economics, 91(1), 237-249. https://dx.doi.org/ 10.1111/j.1467-8276.2008.01164.x

Gasson, R., \& Errington, A. J. (1993). The Farm Family Business. Wallingford, UK: CAB International.

Gasson, R., Errington, A., \& Tranter, R. (1998). Carry on farming: A study of how English farmers have adapted to the changing pressures on farming. London: Imperial College Press.

Gasson, R., Crow, G., Errington, A., Hutson, J., Marsden, T., \& Winter, D. (1988). The farm as a family business: A review. Journal of Agricultural Economics, 39(1), 1-41. http://dx.doi.org/ 10.1111/j.1477-9552.1988.tb00560.x

Glauben, T., Tietje, H., \& Weiss, C. R. (2002). Intergenerational succession on family farms: Evidence from survey data (Working Paper No. 0202). Kiel, Germany: University of Kiel, Department of Food Economics and Consumption Studies. Retrieved from http://citeseerx.ist.psu.edu/viewdoc/down load?doi $=10.1 \cdot 1.577 .6675 \& \mathrm{rep}=$ rep1\&type $=$ pdf

Gloy, B., Boehlje, M., Dobbins, C., Hurt, C., \& Baker, T. (2011). Are economic fundamentals driving farmland values? Choices: The Magazine of Food, Farm, and Resource Issues, 26(2). Retrieved from http://www.choicesmagazine.org/choicesmagazine/theme-articles/farmland-values/areeconomic-fundamentals-driving-farmland-values

Goeller, D. (2012). Facilitating succession and retirement in U.S. agriculture: The case of Nebraska. In M. Lobley, J. R. Baker, \& I. Whitehead (Eds.), Keeping it in the family: International perspectives on succession and retirement on family farms (pp. 149-163). Surrey, UK: Ashgate Publishing.

Hamilton, L. B. (2005). Agricultural land trusts: Preserving small farm heritage. Winnipeg, Manitoba: Canadian Centre for Policy Alternatives.

Higby, A., Ruhf, K., \& Woloschuk, A. (2004). Holding ground: A guide to Northeast farmland tenure and stewardship. Belchertown, Massachusetts: New England Small Farm Institute.

Howell, J. L., \& Habron, G. B. (2004). Agricultural landowners' lack of preference for Internet extension. Journal of Extension, 42(6). Retrieved from http://www.joe.org/joe/2004december/a7.php

Hubbard, P. F. (2006). A land link for western Montana: Keeping land in agriculture from one generation to the next (Master's thesis, University of Montana, Environmental Studies Department). Retrieved from http://scholarworks.umt.edu/etd/267/

Hubona, G. S., \& Geitz, S. (1997). External variables, beliefs, attitudes and information technology usage behavior. In R. H. Sprague (Ed.), System Sciences, 1997, Proceedings of the Thirtieth Hawaii International Conference on System Sciences, v. 3 (pp. 21-28). Los Alimotos, California: IEEE Computer Society Press. http://dx.doi.org/10.1109/HICSS.1997.661560 
Ilbery, B., Ingram, J., Kirwan, J., Maye, D., \& Prince, N. (2012). Non-successional entry into UK farming: An examination of two government-supported schemes. In M. Lobley, J. R. Baker, \& I. Whitehead (Eds.), Keeping It in the family: International perspectives on succession and retirement on family farms (pp. 111127). Surrey, UK: Ashgate Publishing.

Ingram, J., \& Kirwan, J. (2011). Matching new entrants and retiring farmers through farm joint ventures: Insights from the Fresh Start initiative in Cornwall, UK. Land Use Policy, 28(4), 917-927. http://dx.doi. org/10.1016/j.landusepol.2011.04.001

Inwood, S. (2013). Social forces and cultural factors influencing farm transition. Choices: The Magazine of Food, Farm, and Resource Issues, 28(2), 1-5. Retrieved from http://choicesmagazine.org/choicesmagazine/theme-articles/transitions-inagriculture/social-forces-and-cultural-factorsinfluencing-farm-transition\#sthash. FD4Ba1hm.dpuf

Inwood, S. M., \& Sharp, J. S. (2012). Farm persistence and adaptation at the rural-urban interface: Succession and farm adjustment. Journal of Rural Studies, 28(1), 107-117. http://dx.doi.org/10.1016/j.jrurstud.2011.07.005

Inwood, S., Clark, J. K., \& Bean, M. (2013). The differing values of multigeneration and first-generation farmers: Their influence on the structure of agriculture at the rural-urban interface. Rural Sociology, 78(3), 346-370. http://dx.doi.org/10.1111/ruso.12012

Johnston, T., \& Bryant, C. (1987). Sustaining agriculture near cities. In W. Lockeretz (Ed.), Sustaining agriculture near cities (pp. 9-22). Ankeny, Iowa: Soil and Water Conservation Society.

Keating, N., \& Munro, B. (1989). Transferring the family farm: Process and implications. Family Relations, 38(2), 215-218. http://dx.doi.org/10.2307/583678

Khanal, A. R., \& Mishra, A. K. (2013, February). Assessing the impact of internet access on household incomes and financial performance of small farms. Paper presented at the annual meeting of the Southern Agricultural Economics Association, Orlando, Florida. Retrieved from http://ageconsearch.umn.edu/bitstream/143019/1 LSAEA paper Aditya re 18Jan.pdf

Kuethe, T.H., Ifft, J., \& Morehart, M. (2011). The influence of urban areas on farmland values. Choices: The Magazine of Food, Farm, and Resource Issues, 26(2). Retrieved from http://www.choicesmagazine. org/UserFiles/file/cmsarticle 30.pdf

Kirkpatrick, J. (2013). Retired farmer-An elusive concept. Choices: The Magazine of Food, Farm, and Resource Issues, 28(2), 1-5. Retrieved from http://www.choicesmagazine.org/UserFiles/file/c msarticle 305.pdf

Kuehne, G. (2013). My decision to sell the family farm. Agriculture and Human Values, 30(2), 203-213. http://dx.doi.org/10.1007/s10460-012-9393-7

Lemire, S. T., Nielsen, S. B., \& Dybdal, L. (2012). Making contribution analysis work: A practical framework for handling influencing factors and alternative explanations. Evaluation, 18(3), 294-309. http://dx.doi.org/10.1177/1356389012450654

Lindstrom, M. J., \& Bartling, H. (2003). Culture and society: Contested visions and values. In M. J. Lindstrom \& H. Bartling (Eds.), Suburban sprawl: Culture, theory, and politics (pp.1-3). Lanham, Maryland: Rowman \& Littlefield.

Liu, Z., Adams, M., Cote, R., Geng, Y., \& Li, Y. (2016) Comparative study on the pathways of industrial parks towards sustainable development between China and Canada. Resources, Conservation and Recycling. Advance online publication. http://dx.doi.org/10.1016/j.resconrec.2016.06.012

Lobley, M., \& Baker, J. R. (2012). Succession and retirement in family farm businesses. In M. Lobley, J. R. Baker, \& I. Whitehead (Eds.), Keeping it in the family: International perspectives on succession and retirement on family farms (pp. 1-20). Surrey, UK: Ashgate Publishing.

Lyson, T. A. (2007). Civic agriculture and the North American food system. In C. Hinrichs \& T. A. Lyson (Eds.), Remaking the North American food system: Strategies for sustainability (pp. 19-32). Lincoln: University of Nebraska Press.

Mailfert, K. (2007). New farmers and networks: How beginning farmers build social connections in France. Journal of Economic and Social Geography, 98(1), 21-31. http://dx.doi.org/10.1111/j.14679663.2007.00373.x

Mayne, J. (2001). Addressing attribution through contribution analysis: Using performance measures sensibly. Canadian Journal of Program Evaluation, 16(1), $1-24$. 
Mayne, J. (2008). Contribution analysis: An approach to exploring cause and effect (Institutional Learning and Change Initiative Brief No. 16). Retrieved from the BetterEvaluation website: http://betterevaluation.org/resources/guides/cont ribution_analysis/ilac_brief

Mayne, J. (2012). Contribution analysis: Coming of age? Evaluation, 18(3), 270-280. https://dx.doi.org/10.1177/1356389012451663

McGuire, J., Morton, L. W., \& Cast, A. D. (2013). Reconstructing the good farmer identity: Shifts in farmer identities and farm management practices to improve water quality. Agriculture and Human Values, 30(1), 57-69. http://dx.doi.org/10.1007/s10460012-9381-y

Mishra, A. K., El-Osta, H. S., \& Johnson, J. D. (2004, August). Succession in family farm business: Empirical evidence from the U.S. farm sector. Paper presented at the annual meeting of the American Agricultural Economics Association, Denver, Colorado. http://purl.umn.edu/20114

Mishra, A., Johnson, J., \& Morehart, M. (2003, September). Retirement and succession planning of farm households: Results from a national survey. Paper presented at the National Public Policy Education Committee, Salt Lake City, Utah. Retrieved from http://www.farmfoundation.org/news/articlefiles/ 85-mishrapaper10-1-03_version3.pdf

Mishra, A. K., \& Park, T. A. (2005). An empirical analysis of Internet use by U.S. farmers. Agricultural and Resource Economics Review, 34(2), 253-264. https://dx.doi.org/10.1017/S1068280500008406

Nickerson, C. J., Morehart, M., Kuethe, T., Beckman, J., Ifft, J., \& Williams, R. (2012). Trends in U.S. farmland values and ownership (EIB-92). Washington, DC: USDA, Economic Research Service. Retrieved from www.ers.usda.gov/publications/pubdetails $/$ ?pubid $=44660$

Olson, R. K. (1999). A landscape perspective on farmland conversion. In R. K. Olson \& T. A. Lyson (Eds.), Under the blade: The conversion of agricultural landscapes (pp. 53-95). Boulder, Colorado: Westview Press.

O’Neill, B., Komar, S. J., Brumfield, R. G., \& Mickel, R. (2010). Later life farming: Retirement plans and concerns of farm families. Journal of Extension, 48(4),
Article No. 4FEA6. Retrieved from http://joe.org/ joe/2010august/pdf/JOE v48 4a6.pdf

Pitts, M. J., Fowler, C., Kaplan, M. S., Nussbaum, J., \& Becker, J. C. (2009). Dialectical tensions underpinning family farm succession planning. Journal of Applied Communication Research, 37(1), 5979. http://dx.doi.org/10.1080/00909880802592631

Potter, C., \& Lobley, M. (1992). Aging and succession on family farms: The impact on decision-making and land-use. Sociologia Ruralis, 32(2-3), 317-334. http://dx.doi.org/10.1111/j.14679523.1992.tb00935.x

Robison, L. J., Myers, R.J., \& Siles, M. E. (2002). Social capital and the terms of trade for farmland. Review of Agricultural Economics, 24(1), 44-58. https://dx.doi.org/10.1111/1058-7195.00005

Scott, J., Cameron, S. D., \& Benjamin, C. (2010). Opportunities and challenges in Atlantic agriculture. Retrieved from http://nsfa-fane.ca/wp-content/ uploads/2011/06/CrisiOpportunity SCREEN.pdf

Shadish, W. R., Cook, T. D., \& Leviton, L. C. (1991). Foundations of program evaluation: Theories of practice. Newbury Park, California: SAGE.

Sharp, J., \& Smith, M. (2003). Social capital and farming at the rural-urban interface: The importance of nonfarmer and farmer relations. Agricultural Systems, 76(3), 913-927. http://dx.doi.org/10.1016/S08832927(02)00083-5

Shute, L. L., Anderson, A., Bernhardt, H., Creech, T., Fleming, S. V., Oakley, E., \& Shute, B. (2011). Building a future with farmers: Challenges faced by young, American farmers and a national strategy to help them succeed. Hudson, New York: National Young Farmers' Coalition. Retrieved from http://www.youngfarmers.org/newsroom/building -a-future-with-farmers-october-2011/

Slack, T. (2013). Bridging the gap: Farm transition challenges facing elder farmers and the need for a nationwide farm-on program. The Elder Law Journal, 20(2), 485-520. Retrieved from http://publish.illinois.edu/elderlawjournal/archives

Stenberg, P. L., \& Morehart, M. J. (2007). Age in the Internet age: Is the age of the farm operator a factor in online business use? Rochester, New York: Social Science Research Network. Retrieved from https://ssrn.com/abstract $=2110228$ 
Stiglbauer, A. M., \& Weiss, C. R. (1999). Family and nonfamily succession in the upper-Austrian farm sector (Working Paper No. 0008). Kiel, Germany: University of Kiel, Department of Food Economics and Consumption Studies. Retrieved from http://citeseerx.ist.psu.edu/viewdoc/download?doi $=10.1 .1 .467 .3026 \& \mathrm{rep}=$ rep1\&type $=$ pdf

Strange, M., Thompson, N., Prosch, A., \& Johnson, J. (2003). The Nebraska Center for Rural Affairs' land link program. In H. P. Diaz, J. Jaffe, \& R. Stirling (Eds.), Farm communities at the crossroads (pp. 173189). Regina, Saskatchewan: University of Regina Press.

Taragola, N. M., \& Van Lierde, D. F. (2010). Factors affecting the Internet behaviour of horticultural growers in Flanders, Belgium. Computers and Electronics in Agriculture, 70(2), 369-379. http://dx.doi.org/10.1016/j.compag.2009.09.004

Thompson, A. W., \& Prokopy, L. S. (2009). Tracking urban sprawl: Using spatial data to inform farmland preservation policy. Land Use Policy, 26(2), 194-202. http://dx.doi.org/10.1016/j.landusepol.2008.02.00 $\underline{5}$

U.S. Department of Agriculture, National Agricultural Statistics Services [USDA, NASS]. (2007a). 2007 Census of agriculture: Demographics. Retrieved from http://www.agcensus.usda.gov/Publications/ 2007/Online_Highlights/Fact_Sheets/Demographi cs/demographics.pdf

USDA, NASS. (2007b). 2007 Census of agriculture: Farm numbers. Retrieved from http://www.agcensus.usda.gov/Publications/2007 LOnline Highlights/Fact Sheets/Farm Numbers/ farm_numbers.pdf

USDA, NASS. (2007c). 2007 Census of agriculture: New farms, new farm operators. Retrieved from http://www.agcensus.usda.gov/Publications/2007 LOnline Highlights/Fact Sheets/Farm Numbers/ new farms.pdf

USDA, NASS. (2012). 2012 Census of agriculture: Summary and state data. Retrieved from http://www.agcensus.usda.gov/Publications/2012 /Full Report/Volume 1, Chapter 1 US/usv1.pdf USDA, NASS. (2013). Farm computer usage and ownership. Retrieved from http://usda.mannlib. cornell.edu/usda/nass/FarmComp/2010s/2013/ FarmComp-08-20-2013.pdf

USDA, NASS. (2014). Farmland ownership and tenure. Retrieved from https://www.agcensus.usda.gov/ Publications/2012/Online_Resources/Highlights/ TOTAL/TOTAL Highlights.pdf

U.S. Department of Commerce, National Telecommunications and Information Administration. (2011). Digital nation: Expanding internet usage. Retrieved from http://www.ntia.doc.gov/files/ntia/publica tions/ntia internet use report february 2011.pdf

U.S. Environmental Protection Agency [U.S. EPA]. (2013). Ag 101: Demographics [Presentation]. Retrieved from https://www.epa.gov/sites/ production/files/2015-07/documents/ ag 101 agriculture us epa 0.pdf

Varble, S., Secchi, S., \& Druschke, C. G. (2016). An examination of growing trends in land tenure and conservation practice adoption: Results from a farmer survey in Iowa. Environmental Management, 57(2), 2318-2330. https://doi.org/10.1007/s00267-015-0619-5

Warren, M. (2004). Farmers online: Drivers and impediments in adoption of Internet in UK agricultural businesses. Journal of Small Business and Enterprise Development, 11(3), 371-381. https://dx.doi.org/10.1108/14626000410551627

Weber, G., \& Key, N. (2015). Leveraging wealth from farmland appreciation: Borrowing, land ownership, and farm expansion. Land Economics, $91(2), 344$ 361. https://dx.doi.org/10.3368/le.91.2.344

White, J. S. (1998). Beating plowshares into townhomes: The loss of farmland and strategies for slowing its conversion to nonagricultural uses. Environmental Law, 28(1), 113-143. Retrieved from http://heinonline.org/HOL/LandingPage?handle= hein.journals/envlnw28

Zollinger, B., \& Krannich, R. (2002). Factors influencing farmers' expectations to sell agricultural land for non-agricultural uses. Rural Sociology, 67(3), 442-463. https://dx.doi.org/10.1111/j.15490831.2002.tb00112.x 